\title{
Lääketieteen opiskelijoille suunnattu vuorovaikutuskoulutus
}

\author{
Jonna Koponen
}

Lectio praecursoria puheviestinnän väitöskirjaksi tarkoitetun tutkimuksen Kokemukselliset oppimismenetelmät lääketieteen opiskelijoiden vuorovaikutuskoulutuksessa tarkastustilaisuudessa Tampereen yliopistossa 8.6.2012. Vastaväittäjänä toimi professori Sari Lindblom-Ylänne ja kustoksena professori Pekka Isotalus.

Lääkärin ammatti on perinteinen professio, joka on yhteiskunnallisesti tärkeä ja arvostettu. Mutta millainen on hyvä lääkäri? Varmasti meillä kaikilla on omakohtaisia kokemuksia lääkärissä käynnistä, sillä jokainen suomalainen käy lääkärissä keskimäärin 2-3 kertaa vuodessa. Lääkärin ja potilaan kohtaamisia tapahtuu vuosittain miljoonia ja jokainen niistä on ainutkertainen ja ainutlaatuinen. Uskoisin, että jokaisella meillä on henkilökohtainen käsitys siitä, millainen on hyvä lääkäri ja millaiset piirteet kuvaavat onnistunutta vuorovaikutusta lääkärin vastaanotolla.

Tutkimusten mukaan potilaat odottavat lääkäriltä lääketieteellisen asiantuntemuksen lisäksi vuorovaikutusosaamista, kuten potilaan kuuntelemista. Potilaat arvostavat lääkäreitä, jotka osoittavat välittämistä ja ottavat potilaan näkökulman ja elämäntilanteen huomioon hoitovaihtoehtojen suunnittelussa. Tutkimusten mukaan huonosti toimiva lääkärin ja potilaan välinen vuorovaikutus on keskeinen potilasvalitusten syy. Potilasvalitukset liittyvät usein siihen, että potilas ei ole tullut kuulluksi omassa asiassaan tai hänen mielestään lääkäri oli töykeä tai vähätteli potilaan asiaa. Toisaalta onnistunut vuorovaikutus lisää potilaan ja lääkärin tyytyväisyyttä. Se auttaa potilasta ymmärtämään ja noudattamaan hoito-ohjeita ja on yhteydessä myös potilaan kohentuneeseen terveydentilaan. Viimeisimmän Lääkärikyselyn mukaan myös lääkärit tiedostavat vuorovaikutus- ja yhteistyötaitojen merkityksen työnsä tavoitteiden saavuttamisessa. Vuorovaikutusosaamisella on siis keskeinen merkitys lääkärin työssä, mutta kuinka sitä on heille koulutettu?

Vuorovaikutusopinnot ovat vakiintuneet osaksi lääkäreiden peruskoulutusta vasta 1990-luvun aikana sekä ulkomailla että Suomessa. Aiemmin ajateltiin, että lääketieteen opiskelijat oppivat vuorovaikutusosaamista seuraamalla kokeneempien kollegojen työskentelyä ja siirryttyään työelämään. Vuorovaikutustaitojen ajateltiin ikään kuin siirtyvän lääkärisukupolvelta toiselle ilman varsinaista koulutusta. Nykyisin lääkärin työssä tarvittavan vuorovaikutusosaamisen oppimista 
ei jätetä pelkän mallioppimisen tai työssä oppimisen varaan, sillä tiedetään, että roolimallin arvojen, asenteiden ja toimintatapojen omaksuminen ei useinkaan tapahdu tietoisesti. Lisäksi tiedetään, että työkokemus ja työssäoloaika eivät yksistään vaikuta kohentavasti lääkäreiden vuorovaikutusosaamiseen.

Nykyisin vuorovaikutusopinnot ovat hyvin edustettuina lääketieteen koulutusyksiköissä esimerkiksi Yhdysvalloissa ja Iso-Britanniassa. Suomessa vuorovaikutusopintoja kuuluu lääketieteen peruskoulutukseen kaikissa lääketieteen koulutusyksiköissä, mutta niiden laajuudet ja sisällöt vaihtelevat eri yliopistojen välillä.

Lääketieteen vuorovaikutuskoulutusta ei ole maassamme juurikaan tutkittu, mutta kansainvälistä tutkimusta aiheesta löytyy runsaasti. Tutkimuksissa on osoitettu, että vuorovaikutuskoulutukseen osallistuneiden lääketieteen opiskelijoiden ja asiantuntijoiden vuorovaikutustaidot ovat kohentuneet koulutuksen myötä. Kokemukselliset oppimismenetelmät ovat osoittautuneet tehokkaammiksi vuorovaikutustaitojen oppimisessa kuin luennot tai mallioppiminen.

Tällä hetkellä lääketieteen vuorovaikutuskoulutuksessa suosittuja kokemuksellisia oppimismenetelmiä ovat roolipeli ja simuloidut potilaat. Koulutuksissa on käytetty myös teatteriesitystä, improvisaatiotekniikoita ja opiskelijoiden itsensä valmistamia pienoisnäytelmiä. Osallistavan draamakasvatuksen genrejä, kuten työpajateatteria, ei ole aiemmin sovellettu lääketieteen vuorovaikutuskoulutukseen. Erilaisia kokemuksellisia oppimismenetelmiä ei ole aiemmin juuri vertailtu. Aiemmissa tutkimuksissa ei ole kiinnitetty laajasti huomiota lääketieteen opiskelijoiden näkemyksiin erilaisista oppimismenetelmistä. Opiskelijoiden näkemysten tarkastelu on tärkeää, koska kokemuksellisissa oppimismenetelmissä oppijan aktiivisuus ja osallistuminen ovat keskeisiä oppimisen kannalta. Erilaiset menetelmät mahdollistavat erilaisen oppimiskokemuksen. Täten on tärkeää tutkia, millaiset oppimismenetelmät soveltuvat millekin kohderyhmälle, millaisia oppimistuloksia niiden avulla voidaan saavuttaa ja millaiset erityispiirteet kussakin menetelmässä ovat oppimista tukevia tai heikentäviä.

Tässä väitöskirjatutkimuksessa kuvataan ja verrataan lääketieteen opiskelijoiden näkemyksiä työpajateatterin, simuloitujen potilaiden ja roolipelin erityispiirteistä sekä menetelmien soveltuvuudesta vuorovaikutusosaamisen oppimiseen. Vuorovaikutuskoulutuksen vaikuttavuutta arvioidaan opiskelijoiden itsearvioitujen oppimistulosten ja asenteiden muuttumisen näkökulmista sekä vertaamalla oppimistuloksia koulutukselle asetettuihin tavoitteisiin. Tutkimus on monimenetelmäinen tapaustutkimus, joka koostuu neljästä osatutkimuksesta. Tutkimusmenetelminä olivat kyselylomake, täsmäryhmähaastattelut ja suomennettu vuorovaikutustaitojen oppimisen asennemittari.

Tutkimuksessa toteutettiin puheviestinnän opetuskokeilu, johon osallistui 132 lääketieteen toisen vuosikurssin opiskelijaa. Tutkimuksen aineisto kerättiin Kuopion yliopistossa, joka on nykyisin Itä-Suomen yliopisto. Puheviestinnän 
opinnot olivat tulleet osaksi lääketieteen peruskoulutusta vuonna 2004, mutta opiskelijapalautteen perusteella niihin kaivattiin sisällöllistä ja menetelmällistä muutosta. Sain työtehtäväkseni lääketieteen opiskelijoiden puheviestinnän koulutuksen uudistamisen.

Tutkimuksen kohteena ollut puheviestinnän opetuskokeilu perustui alakohtaiseen viestintäpedagogiikkaan. Sen näkökulmasta vuorovaikutusosaaminen määrittyy alakohtaisesti ja oppiminen tapahtuu tilanteeseen sidoksissa olevien vuorovaikutusprosessien kautta sekä osallistumalla asiantuntijayhteisön toimintaan. Alakohtaisen viestintäpedagogiikan näkökulma huomioitiin siten, että puheviestinnän opetus integroitiin terveyssosiologia ja -psykologia opintojaksoon. Opettajina toimivat sekä lääketieteen että puheviestinnän opettajat. Opetukseen sisältyi osallistuminen asiantuntijayhteisön toimintaan, kun opiskelijat havainnoivat ja analysoivat aitoja lääkärin ja potilaan välisiä kohtaamisia terveyskeskuspäivien aikana.

Alakohtaisen viestintäpedagogiikan lähtökohtia voidaan kuitenkin myös kritisoida. Se tarkastelee oppimista alasidonnaisen kontekstin ja vuorovaikutuksen kautta. Se ei tarkastele opiskelijan omaan toimintaan liittyviä vaatimuksia tai oppimistilanteessa syntyvien kokemusten ja niiden reflektoinnin avulla tapahtuvaa oppimista. Se ei myöskään selitä, kuinka yksilö voi konstruoida tietoa. Lisäksi asiantuntijayhteisöön osallistumalla tapahtuvaan oppimiseen voi sisältyä se riski, että samat rutiinit ja totutut ajatusmallit siirtyvät tiedostamatta ammattilaisilta nuoremmille kollegoille. Siksi tässä tutkimuksessa alakohtaisen viestintäpedagogiikan teoriataustaa laajennetaan ja käytetään konstruktivistista oppimisnäkemystä, kokemuksellista oppimista ja draamakasvatuksen alaan kuuluvaa esteettisen kahdentumisen teoreettista käsitettä. Tutkimuksessa ajatellaan, että oppiminen on oppijan aktiivista kognitiivista ja sosiaalista toimintaa. Tällöin oppija valikoi ja tulkitsee informaatiota ja rakentaa ymmärryksensä maailmasta ja sen ilmiöistä pohjaten tulkintansa aiempiin tietoihin, käsityksiin ja kokemuksiin. Oppiminen tapahtuu sosiaalisessa ja kulttuurisessa kontekstissa, jolloin myös oppimistilanteessa tapahtuva vuorovaikutus on tärkeää oppimisen kannalta. Tiedon ja ymmärryksen rakentuminen voi tapahtua kokemuksen ja sen reflektoinnin avulla ja myös vertaamalla fiktiivisen ja sosiaalisen todellisuuden kokemuksia keskenään.

Tässä tutkimuksessa luotiin vertaileva tutkimusasetelma, jossa lääketieteen opiskelijat jaettiin satunnaisesti kolmeen ryhmään. Aluksi kaikki opiskelijat osallistuivat info-tilaisuuteen ja ryhmäopetukseen, joiden tavoitteena oli orientoida heitä tuleviin vuorovaikutusharjoituksiin. Sen jälkeen opetus tapahtui ryhmissä A, B ja C.

Ryhmässä A käytettiin työpajateatteria, joka on kehittynyt Iso-Britanniassa 1960-luvun puolivälissä. Työpajateatteriin sisältyi lämmittelyvaihe, näytelmän katsomisvaihe sekä työpajatyöskentely. Koulutetut harrastajanäyttelijät esittivät aitoihin potilastapauksiin perustuneen pienoisnäytelmän, jota lääketieteen opis- 
kelijat kollektiivisesti tarkastelivat. Näytelmät sisälsivät vuorovaikutushaasteita. Lääkäri ei esimerkiksi ottanut riittävästi katsekontaktia potilaaseen, ei vastannut potilaan huoliin eikä kuunnellut potilasta tarkkaavaisesti. Näytelmän herättämiä ajatuksia tarkasteltiin pari- ja pienryhmäkeskustelun, draamakasvatuksen työtapojen sekä sovelletun foorumiteatterin keinoin. Sovelletussa foorumiteatterissa näytelmän kohtaus esitettiin uudelleen ja opiskelijat saivat pysäyttää sen heti kun heistä tuntui, että lääkäri voisi muuttaa viestintäkäyttäytymistään. Opiskelijat tekivät ehdotuksia tilanteen muuttamiseksi ja saivat itse kokeilla, kuinka tilanteessa voisi toimia toisin. Työpajan lopuksi opiskelijat reflektoivat työskentelyä itsenäisesti ja kollektiivisesti.

Ryhmässä B oppimismenetelmänä käytettiin simuloituja potilaita. Simuloitu potilas tarkoittaa koulutettua henkilöä, joka eläytyy ennalta sovittuun potilastapaukseen. Niitä on käytetty lääketieteen opetuksessa ja tutkimuksessa jo 1960-luvulta alkaen. Simuloidut potilaat mahdollistavat vuorovaikutusosaamisen harjoittelun todentuntuisessa ja turvallisessa oppimisympäristössä ilman pelkoa siitä, että harjoittelusta olisi haittaa tai vaaraa aidoille potilaille. Tässä tutkimuksessa simuloituina potilaina toimivat koulutetut harrastajanäyttelijät ja potilastapaukset perustuivat aitoihin potilastapauksiin. Niiden teemoina olivat muun muassa flunssa, päänsärky ja selkäsärky. Vuorovaikutusharjoituksessa lääketieteen opiskelijat olivat vuorollaan lääkärin roolissa ja haastattelivat potilasta. Harjoituksen jälkeen lääkärinä ollut opiskelija arvioi omaa toimintaansa ja sai palautetta simuloidulta potilaalta sekä vertaisryhmän jäseniltä ja opettajalta.

Ryhmässä C käytettiin roolipeliä. Roolipelissä opiskelijat olivat itse sekä lääkärin että potilaan rooleissa. Muutoin harjoituksen kulku ja potilastapaukset olivat täysin samanlaisia kuin ryhmässä B, joissa potilaan roolissa olivat simuloidut potilaat.

Ryhmäopetuksen jälkeen kaikki opiskelijat osallistuivat terveyskeskuspäiville, joilla he tutustuivat lääkärin työhön kahden päivän ajan. Puheviestinnän opetukseen liittyen heidän tehtävänään oli havainnoida ja analysoida aitoja lääkärin ja potilaan välisiä vuorovaikutustilanteita sekä kirjoittaa havainnoistaan raportti. Viimeisessä kahden tunnin kokoontumisessa analysointitehtävät käsiteltiin pienryhmissä.

Millaisia tuloksia tutkimuksessa saatiin? Ensinnäkin tulokset osoittivat, että vähintään $84 \%$ kussakin ryhmässä olleista opiskelijoista koki työpajateatterin, simuloitujen potilaiden ja roolipelin soveltuvan hyvin tai erittäin hyvin vuorovaikutusosaamisen oppimiseen. 5-7 \% kussakin ryhmässä olleista opiskelijoista ajatteli, että nämä menetelmät eivät soveltuneet hyvin vuorovaikutusosaamisen oppimiseen. Eri ryhmissä olleiden opiskelijoiden näkemyksissä ei havaittu tilastollisesti merkitseviä eroja. Menetelmien samankaltaiset erityispiirteet olivat lääkärin rooli, potilaan rooli, reflektiivinen osallistuminen, tunnereaktiot ja opettajien toiminta. Toiseksi tulokset näyttivät, että opiskelijat kokivat oppineensa hyvin samansuuntaisia asioita kaikissa kolmessa ryh- 
mässä. He itsearvioivat oppineensa vuorovaikutustaitoja ja uutta tietoa lääkäripotilasvuorovaikutuksesta. Opiskelijat kokivat tulleensa tietoisiksi sekä omasta että lääkärin työssä vaadittavasta vuorovaikutusosaamisesta. Lisäksi he oppivat potilaskeskeisyyttä, mitä voi pitää tärkeänä tuloksena ajatellen heidän tulevia potilaskohtaamisiaan. Pieni osa vastaajista ei kokenut oppineensa mitään uutta. Kolmanneksi tulokset osoittivat, että opiskelijoiden asenteet vuorovaikutustaitojen oppimista kohtaan muuttuivat myönteisemmiksi vuorovaikutuskoulutuksen aikana. Kolmen ryhmän välillä ei havaittu tilastollisesti merkitseviä eroja opiskelijoiden asenteissa. Tulokset olivat positiivisempia kuin vastaavissa kansainvälisissä tutkimuksissa.

Puheviestinnän opetuskokeilulle asetetut tavoitteet saavutettiin suhteellisen hyvin. Tulosten tarkastelun perusteella esitän teoreettisen ajatuksen siitä, että tutkimuksen kohteena olleet kokemukselliset oppimismenetelmät tarjoavat osallistujille kolme erilaista osallistumisen tasoa, joilla vuorovaikutusosaamista on mahdollista oppia. Näitä ovat 1) vuorovaikutustilanteiden havainnointi ja analysointi, 2) reflektiivinen osallistuminen toiminnan aikana ja toiminnan jälkeen sekä 3) toiminta lääkärin ammattiroolissa. Lisäksi turvallinen oppimisilmapiiri tukee vuorovaikutusosaamisen oppimista näiden menetelmien avulla.

Tämän tutkimuksen anti kiteytyy kolmeen pääkohtaan. Ensinnäkin tulosten perusteella kaikki tutkitut menetelmät soveltuvat hyvin lääketieteen opiskelijoiden vuorovaikutuskoulutukseen. Tulokset rohkaisevat käyttämään näitä menetelmiä lääketieteen vuorovaikutuskoulutuksessa myös tulevaisuudessa. Toiseksi tutkimuksen avulla saatiin uutta tietoa alakohtaisessa vuorovaikutuskoulutuksessa saavutetuista oppimistuloksista. Se on tärkeää puheviestinnän opetuksen kehittämiseksi. Kolmanneksi tutkimuksessa löydettiin uusi kokemuksellinen oppimismenetelmä, työpajateatteri. Tulosten perusteella se soveltuu lääketieteen vuorovaikutuskoulutukseen yhtä hyvin kuin perinteisemmin käytetyt roolipeli ja simuloidut potilaat. 